\title{
Mitigating Uncertainty in the Boardroom: Analysis to Financial Reporting for Financial Risk COVID-19
}

\author{
Ali Khazaal JABBAR ${ }^{1}$, Aymen Raheem Abdulaali ALMAYYAHI ${ }^{2}$, Ibrahem Mohamed ALI ${ }^{3}$, Alhamzah ALNOOR ${ }^{4}$
}

Received: September 01, 2020 Revised: October 26, 2020 Accepted: November 05, 2020

\begin{abstract}
This study aims to assess the impacts of COVID-19 on International Financial Reporting Standards (IFRS), because of the problems associated with changing and amending the financial reports according to the policies established based on the circumstances of the epidemic. The study sample targeted several international financial reports that were amended based on epidemic conditions. The revised financial reporting period provides standardized reporting procedures for financial transactions worldwide despite the pandemic. Therefore, IFRS has been used to reduce challenges in financial reporting by monitoring the duration of social distancing while reporting matters to eliminate confirmed uncertainty and judgment. After analyzing the data obtained through global search engines, the results conducted provided evidence that COVID-19 affects financial reporting in companies around the world. Therefore, companies face difficulty reporting finances based on the challenging environment that the pandemic represents. Besides, IFRS fair value measurements consider the prices that were predicted according to current market values. The contexts of the changing the standards by IFRS to curb the effects of the COVID19 financial reporting was attained through evaluation of the online files that were randomly selected and filtered to obtain valid data.
\end{abstract}

Keywords: Financial Reporting, Covid-19, Financial Risks, International Standards, Mitigating Uncertainty

JEL Classification Code: C58, G10, E6, F65, G15

\section{Introduction}

International Financial Reporting Standards (IFRS) is a body that sets policies and common rules to safeguard the integrity of describing the financial performance of firms so

${ }^{1}$ First Author. Assistant Lecturer, Department Business of Administration, College of Administration and Economics, Universityy of Misan, Iraq. Email: Ali-khazaal@uomisan.edu.iq

${ }^{2}$ Lecturer, Accounting Technical Department, Management Technical College, Southern Technical University, Basrah, Iraq.

Email: Aymen.abdulali@stu.edu.iq

${ }^{3}$ Assistant Lecturer, Department of Accounting, College of Administration and Economics, University of Al Hamdaniya, Iraq. Email: Ibrahemsaleem@uohamdaniya.edu.iq

${ }^{4}$ Corresponding Author. [1] Lecturer, Management Technical College, Southern Technical University, Iraq [2] PhD Student, School of Management, Universiti Sains Malaysia, Malaysia [Postal Address: Pulau Pinang, Pinang, Gelugor, 11800, Malaysia]

Email: Alhamzah.alnoor@student.usm.my ; Alhamzah.malik@stu. edu.iq

(C) Copyright: The Author(s)

This is an Open Access article distributed under the terms of the Creative Commons Attribution Non-Commercial License (https://creativecommons.org/licenses/by-nc/4.0/) which permits unrestricted non-commercial use, distribution, and reproduction in any medium, provided the original work is properly cited. that company financial statements are understandable and comparable across global boundaries. IFRS was established to bring consistency to accounting standards and practices, irrespective of the company or the country. According to the international standards of accounting and reporting, IFRS requires companies to exercise professional judgment that helps firms to develop good reporting systems of their financial accounting outcomes (financial performance). However, IFRS face difficulties during the development of policies and designs of the financial reporting systems. In addition, the coronavirus 2019 (COVID-19) pandemic is the current external issue that is affecting the guidelines of financial reporting systems. The company's financial accounting and performance reporting guidelines have been affected by COVID-19 across various industries. The virtual operating industries' financial performance reporting system has been the most affected during the COVID-19 trading periods. The COVID-19 difficulties are associated with the impacts on IFRS principles and ethics due to the need for various adjustments to ensure clarity and appropriateness in financial accountability reporting. IFRS policies are useful in reporting the financial performance of firms; however, due to the COVID-19 pandemic, it has been a vigorous requirement 
to adjust some of the policies to suit the financial accounting and reporting procedure. The conditions of the COVID-19 are creating challenges in financial markets in terms of accounting and reporting uncertainties (Tahir et al., 2020; Alhamdi et al., 2019). For example, hospitality, leisure, travel entities, and e-commerce operations are declining due to COVID-19 effects on their financial accountability. Most of the financial outcomes reporting effects have been facing both local and international IFRS regulations that affect dayto-day conditions of the presentations of the financial reports (Fernandes, 2020; Dang et al., 2020).

Additionally, the closure of some of the entities affected the financial data sharing systems hence interfering with the integrated reporting system of the financial status. Social distancing has reduced the perfection of the financial results reporting by the auditing and accounting consulting team. Changes to IFRS across the financial global reporting system are currently based on the conditions of COVID-19. (Fernandes, 2020). Therefore, this factor is a going concern in IFRS for financial reporting and accountability (Tahir et al., 2020).

IFRS develops evaluation programs for companies to help in tracking accounting and reporting financial outcomes. The evaluation helps firms to understand how to cope with the current situation based on adjustments made to IFRS due to the effect of COVID-19. Theories supporting the effects of COVID-19 on IFRS will be analyzed in this study to show the newly adopted ways of reducing the companies' constraints in financial reporting (Asumadu et al., 2018). Based on various existing theories of financial reporting concepts, the study will utilize the reporting concepts applied by the companies to evaluate various financial transactions across financial fields (Steccolini, 2019). Besides, the study will investigate the potential IFRS changes that have been occurring due to the COVID-19 pandemic. Additionally, the project will determine the potential solution for the financial reporting constraints caused by COVID-19. Moreover, the research will influence the studying of the potential changes that firms require to achieve their objects and goals of reporting financial outcomes (Steccolini, 2019). Therefore, the financial reporting project will have various theories expressed under the foundation of the metrics of firms' performance in the current world financial reporting systems (Bharti \& Kumar, 2020; Sumani \& Roziq, 2020).

The research problem is the gap between the existing methods of IFRS policies and rules for reporting financial performance and the potential changes in IFRS due to the COVID -19 pandemic effects. The COVID-19 pandemic affected IFRS principles that guide the financial reporting concepts in various firms. The impacts on financial accounting and reporting procedures have affected companies' focusing on strategizing models (Fernandes, 2020; Hadi et al., 2018). Governance of financial resources has been difficult due to the requirement of changes to IFRS across various industries thereby necessitating costly adjustments in order to merge with new methods of reporting financial outcomes of firms (Tahir et al., 2020). Therefore, for adjustments to circumstances for the continuation of reporting of the financial outcomes of companies appropriately, IFRS policies have created adjustments procedure between the existing conditions and COVID-19 consideration (Duong et al., 2020).

\section{Overview of Financial Reporting}

\subsection{IFRS 2-Share-Based Payment}

IFRS-2 focuses on the effects of the share-based payments after the end of the reporting period. IFRS-2 specifies the reporting procedure in the financial entities that should be operational on the share-based payment transactions. Moreover, the reporting, in this case, involves the share options issued, which is in the form of a transaction within the financial statements. The reports of IFRS-2 include the transaction of the employees and the transactions that involve other parties to be settled in cash, equity instruments, or other assets of the company (Benmelech \& Tzur-Ilan, 2020). Additionally, IFRS-2 reflects on the annual reports of the share-based payment reporting. It necessitates the company to reflect in its reported profit or loss and financial position, the impacts of share-based payment transactions, including expenses related to the transactions wherein share options are given to employees (Fernandes, 2020). The expense has been an inclusive part of the share-based payment reports report according to the transaction in which the shares have been given to the holders or employees.

Table 1: Example of Summary of stock Market

\begin{tabular}{|l|c|}
\hline Open Stock & $\mathbf{2 4 . 5}$ \\
\hline Bid & $24.75 \times 1200$ \\
\hline Ask & $24.44 \times 1200$ \\
\hline Range & $22.86-26.85$ \\
\hline Annuity Range & $17.50-26.85$ \\
\hline Trading Volume & $43,300,000+$ \\
\hline Average & $110,478,500+$ \\
\hline Eps (Fwd) & 1.23 \\
\hline Pe (Ttm) & 16.76 \\
\hline Div Rate (Ttm) & $\$ 4.40$ \\
\hline Yield (TTM) & $9.78 \%$ \\
\hline Market Cap & $66.84 B$ \\
\hline Volume & 25,370 \\
\hline
\end{tabular}


Table 2: Example Dividends Scorecard

\begin{tabular}{|l|c|c|c|c|}
\hline DIVIDEND YIELD (TTM) & ANNUAL PAYOUT (TTM) & $\begin{array}{c}\text { PAYOUT } \\
\text { RATIO }\end{array}$ & 5 YEAR GROWTH RATE & $\begin{array}{c}\text { DIVIDEND } \\
\text { GROWTH }\end{array}$ \\
\hline $9.78 \%$ & $\$ 4.40$ & $358.46 \%$ & $7.47 \%$ & 0 Years \\
\hline
\end{tabular}

Consequently, COVID-19 has been challenging the reporting of the share-based payment to the relevant shareholders. The reporting and extraction of the transaction have been implemented to operate under extended deadlines. All the shareholders should gain a right of disclosure and concern if conditions and events, taken as a whole, raise substantial doubt about the company's ability to meet its obligations (Burton \& Jermakowicz, 2015). For the entity uncertainties on the transaction and share-based reports, the existing performance reports should support the implication of the benefit of doubts. COVID-19 has been a significant challenge to the adjustment of IFRS-2 standard because the subsequent events that occur after reporting financial outcomes require backdates (Benmelech \& Tzur-Ilan, 2020). The disclosure provided about the key assumptions and possible outcomes should reflect the conditions at the reporting date. When key assumptions, or the range of reasonably possible changes to those assumptions, are affected significantly as a result of non-adjusting events after the reporting date, information about those changes, including an estimate of the financial effect, should be provided separately (Asumadu et al., 2018)

\subsection{IFRS-13 Fair Value Measurements (FVM)}

IFRS-13 is one of the standard policies that have been assisting the financial reporting system. Before the changes that have been caused by the COVID-19, IFRS 13 Fair Value Measurement (FVM) applies to IFRSs that require or permit fair value measurements or disclosures and provides a single IFRS framework for measuring fair value (FV) and requires disclosures about FVM. The valuation techniques have been used to present the financial reports to the stakeholders and provided the sensitive values thorough input of Fair Value Metrics. IFRS-13 requires firms to disclose the FVM input to disclose values in the financial reports. Fair value is focused on the assumptions of the market place, is not entity-specific, and therefore considers any assumptions about risk. This means that fair value is measured using the same assumptions used by market participants and takes into account the same characteristics of the asset or liability (Asumadu et al., 2018).

A change in the FVM impacts the disclosures mandatory by IFRS 13, which necessitates companies to disclose the valuation techniques together with the inputs used in the FVM as well as the sensitivity of the valuation to changes in assumptions. Disclosures are required to enable users to comprehend whether COVID-19 has been considered for FVM. An important question is what conditions and the related assumptions were known or knowable to market participants at the reporting date. Disclosure of the valuation assumption is presented in the last reporting date. However, the condition of the COVID-19 outbreak has changed the operation of the IFRS-13 financial instrument.

For the year 2020, operations in financial reporting under IFRS-13 standard has changed to support the system and adjust the financial reporting system against the pandemic. For 2020, FVMs, particularly of financial instruments, must be reviewed to make sure the values reflect the conditions at the balance sheet data (Asumadu et al., 2018) This will entail measurement based on unobservable inputs which reflect how market participants would consider the impact of COVID-19 in their expectations of future cash flows related to the asset/liability at the reporting date.

The reporting of the market price is also based on various valuation techniques of reporting with special attention to FVM due to COVID-19 effects (Asumadu et al., 2018). During the current environment, the volatility of prices on various markets has also increased. This impacts the FVM, that is the fair value is determined based on market prices. For example, IFRS-13 has changed the reporting measures under FVM, such as reporting debt securities and shares in an actively traded market (Asumadu et al., 2018).

\subsection{IFRS-9 Reporting Expected Credit Loss Assessment (ECL)}

IFRS 9 requires that credit losses on financial assets are measured and recognized using the expected credit loss (ECL) approach. There has been a change in usual measures and reporting of the credit loss assessment and expected elements of financial changes due to COVID-19 in the case of financial instruments. The credibility of reporting the financial expectations of the company under IFRS 9 has been incorporated by a reasonable response to members. IFRS- 9 incorporates the past financial events of a firm to support the future forecasting of the expected outcomes. Under the approach required by IFRS 9, it is no longer obligatory for a loss event to have happened, rather an entity is needed to account for ECL on initial recognition of the financial asset and later separately account for changes in the ECL at each reporting date (Asumadu et al., 2018; Al-Abrrow et al., 2019). 
Table 3: Example of Income Statement Report

\begin{tabular}{|l|c|c|c|c|c|}
\hline EBIT Margin (TTM) & $\mathbf{1 4 . 3 2} \%$ & $\mathbf{3 8 . 9 5 \%}$ & $\mathbf{- 6 3 . 2 2 \%}$ & $\mathbf{2 3 . 1 9 \%}$ & $\mathbf{- 3 8 . 2 2 \%}$ \\
\hline EBITDA Margin (TTM) & $1.26 \%$ & $6.37 \%$ & $-80.17 \%$ & $2.89 \%$ & $-56.23 \%$ \\
\hline Net Income Margin (TTM) & $4.56 \%$ & $28.04 \%$ & $-83.75 \%$ & $7.51 \%$ & $-39.31 \%$ \\
\hline Levered FCF Margin (TTM) & $0.82 \%$ & $-4.48 \%$ & $\mathrm{NM}$ & $1.94 \%$ & $-57.86 \%$ \\
\hline Return on Common Equity (TTM) & $-1.62 \%$ & $3.52 \%$ & $\mathrm{NM}$ & $3.39 \%$ & $\mathrm{NM}$ \\
\hline Return on Total Capital (TTM) & $3.17 \%$ & $-10.60 \%$ & $\mathrm{NM}$ & $6.67 \%$ & $-52.51 \%$ \\
\hline Return on Total Assets (TTM) & $1.75 \%$ & $2.67 \%$ & $-34.60 \%$ & $4.08 \%$ & $-57.12 \%$ \\
\hline CAPEX / Sales (TTM) & $1.27 \%$ & $-3.30 \%$ & $\mathrm{NM}$ & $2.97 \%$ & $-57.21 \%$ \\
\hline Asset Turnover Ratio (TTM) & $4.99 \%$ & $13.88 \%$ & $-64.05 \%$ & $3.87 \%$ & $28.82 \%$ \\
\hline Cash from Operations (TTM) & $1.55 \%$ & $34.00 \%$ & $351.36 \%$ & 1.57 & $-1.36 \%$ \\
\hline Net Income Per Employee (TTM) & $14.11 \mathrm{~B}$ & $249.93 \mathrm{M}$ & $5543.81 \%$ & $25.63 \mathrm{~B}$ & $-44.97 \%$ \\
\hline
\end{tabular}

The conditions of the expected credit loss (ECL) for financial assets are not well or fairly valued through the loss and profit accountability. The financial reports as per IFRS-9 require profit or loss to report the assessments of the ECL through information-based consideration of a firm in the reporting date (Asumadu et al., 2018). Events of the reporting date should always be considered to provide extra evidence and elements on the existing information as at the reporting date.

On the other hand, due to the emergency of COVID-19, the increased credit risk faced by banks and lenders is linked to exposures to borrowers in highly impacted sectors. The current ECL assessment reporting requires provisions to be estimated based on the ECL for the remaining extended life of the financial instruments that have a financial significance. Reporting has facilitated short-term receivables due to delayed transactions and credit settlement processing (Asumadu et al., 2018). In that case, the borrowers assess the loan reports as per the issuing guidance of regulators to make sure companies accurately represent ECL and apply IFRS 9 consistently in both long-term and short-term reporting. The specific consideration of reporting is the inclusivity of the financial service and ECL guidance for lenders as well as borrowers instead of only borrowers, which was the previous procedure. In addition to this guidance, the financial reporting of ECL has changed to operate with an associate of IFRS 7 as part of financial reporting tools (Asumadu et al., 2018; Al-Abrrow et al., 2019). The reporting system considers disclosure of the defaulters and loan payable breaches that provides the reports of the ECL in short-term considerations.

\subsection{IFRS-15 Revenue from Contracts with Clients}

IFRS 15 specifies how and when an IFRS reporter will recognize revenue as well as requiring such companies to provide financial reports with more informative and relevant disclosures. IFRS 15 requires entities reporting under IFRS to provide useful information on the nature, amount, timing, and uncertainty of revenue and cash flows from a contract with a customer. IFRS 15 sets out approaches to accounting for contract modification and recognition of the revenue in the contract modification process. Contract modifications are treated as adjustments to the original contract except if they add a further performance obligation which is distinctive and priced-based on an adjusted separate selling price. IFRS-15 considers the effects of assumption in reporting the concerns of the contracts of the firm with the client. The reporting should also have an assumption from the management in revenue measuring (Ozturk \& Karabulut, 2018). Under IFRS 15 a company will recognize revenue to show the transfer of goods/ services to clients in an amount reflecting the consideration to which the company expects to be allowed in exchange for those goods/services. Before the outbreak of COVID-19 Under IFRS 15, if a contract comprises variable consideration, then the company estimates the consideration amount that it is entitled (Ozturk \& Karabulut, 2018). Additionally, the reporting is more effective when discount reports, penalties of delayed deliverables, and price deduction from the client are taken into consideration. That is, companies need to consider carefully whether actions taken to respond to the COVID-19 outbreak result in additional variable consideration

In the reporting of the client's revenue, when a company transfers control of a good or service over time, revenue is recognized by measuring the progress towards complete satisfaction of that performance obligation. Under IFRS 15 determining the timing and amount of revenue to be recognized often requires a company to make estimates and judgments. (Oztrk \& Karabulut, 2018; Eneizan et al., 2019). The COVID-19 outbreak has created uncertainties that can affect these estimates significantly. Companies must update these estimates to reflect the current environment, necessitating significant judgment. (Asumadu et al., 2018). Therefore, IFRS- 15 has been supporting the reporting obligations under contract revenue acquisition hence reducing the presence of the unnecessary concerns in the financial outcome reports (Asumadu et al., 2018). The current discounts and the reduced price have been consistently included in short-term reporting. 
Table 4: Example of Income Financial Statements Report

\begin{tabular}{|c|c|c|c|c|c|c|}
\hline & 2015 & 2016 & 2017 & 2018 & 2019 & 2020 \\
\hline Revenues & $304,640.30$ & $270,788.10$ & $353,554.00$ & $410,789.10$ & $416,563.20$ & $387,097.90$ \\
\hline Other Revenues & - & - & - & - & - & $8,823.90$ \\
\hline Other Revenues & $6,395.70$ & $7,174.00$ & $9,056.80$ & $9,532.00$ & $9,436.40$ & $8,823.90$ \\
\hline Total Revenues & $311,036.00$ & $277,962.10$ & $362,610.80$ & $420,321.10$ & $425,999.70$ & $395,921.80$ \\
\hline Cost of Revenues & $230,118.80$ & $198,705.40$ & $272,127.30$ & $349,848.50$ & $357,649.70$ & $339,211.20$ \\
\hline Gross Profit & $80,917.20$ & $79,256.70$ & $90,483.50$ & $70,472.60$ & $68,350.00$ & $56,710.60$ \\
\hline \multicolumn{7}{|l|}{$\begin{array}{l}\text { Operating Expenses \& } \\
\text { Income }\end{array}$} \\
\hline $\begin{array}{l}\text { Selling General \& Admin } \\
\text { Expenses }\end{array}$ & $19,424.00$ & $18,470.30$ & $21,489.70$ & $19,304.50$ & $18,042.50$ & $17,793.70$ \\
\hline R\&D Expenses & - & - & - & $1,156.60$ & $1,349.30$ & $1,326.50$ \\
\hline Depreciation \& Amortization & $14,857.10$ & $15,615.50$ & $17,721.70$ & - & - & -131 \\
\hline $\begin{array}{l}\text { Other Operating Expense/ } \\
\text { (Income) }\end{array}$ & $35,374.00$ & $32,845.40$ & $36,400.80$ & $35,836.00$ & $34,832.50$ & $31,094.50$ \\
\hline Total Operating Expenses & $71,915.00$ & $70,044.40$ & $78,673.80$ & $57,879.60$ & $55,915.20$ & $51,707.30$ \\
\hline Operating Income & $9,002.20$ & $9,212.30$ & $11,809.70$ & $12,593.00$ & $12,434.80$ & $5,003.30$ \\
\hline \multicolumn{7}{|l|}{$\begin{array}{l}\text { Earnings from Continuing } \\
\text { Operations }\end{array}$} \\
\hline Interest Expense & $-1,252.70$ & $-1,327.70$ & $-1,098.30$ & -855.3 & $-2,238.30$ & $-2,143.30$ \\
\hline $\begin{array}{l}\text { Interest And Investment } \\
\text { Income }\end{array}$ & 535.4 & 501.3 & 847.7 & $2,784.60$ & $2,848.50$ & $2,678.30$ \\
\hline Net Interest Expenses & -717.3 & -826.4 & -250.5 & $1,929.30$ & 610.2 & 535 \\
\hline $\begin{array}{l}\text { Currency Exchange Gains } \\
\text { (Loss) }\end{array}$ & -594.1 & -87.9 & 51 & 86.6 & -24.4 & 82.5 \\
\hline $\begin{array}{l}\text { Other Non-Operating } \\
\text { Income (Expenses) }\end{array}$ & -39.9 & - & - & -350.4 & -204.9 & -201.5 \\
\hline EBT, Excl. Unusual Items & $8,938.90$ & $9,638.40$ & $14,149.90$ & $14,258.60$ & $12,815.60$ & $5,170.80$ \\
\hline EBT, Incl. Unusual Items & $8,688.60$ & $11,543.50$ & $13,324.30$ & $14,611.00$ & $12,927.90$ & $5,281.20$ \\
\hline Income Tax Expense & $1,942.70$ & $2,982.30$ & $2,501.90$ & $2,938.60$ & $2,569.90$ & 681.4 \\
\hline $\begin{array}{l}\text { Earnings From Continuing } \\
\text { Operations }\end{array}$ & $6,745.90$ & $8,561.20$ & $10,822.40$ & $11,672.50$ & $10,358.00$ & $4,599.80$ \\
\hline
\end{tabular}

\subsection{The Impact of COVID-19 to IFRS Adoption}

Most of the firms that had applied IFRS-1 face challenges that affect the foundation of financial reporting. According to IFRS-1, the adoption of the financial reporting system requires a reasonable basis to create effectiveness in reporting the firm's final accountability. Public companies have faced the effects of IFRS adjustments against their standard financial reporting settings (Aymen, 2018). The application and adoption of IFRS have been easy due to the existing and well-known financial reporting procedures.
However, the COVID-19 impact has been causing new development in firms' final accounting preparation. The reporting timing has been adjusted into short terms to represent the financial status effects according to the pandemic conditions. The issuance of IFRS policy changes related to financial reporting to the new companies that have adopted them during COVID-19 had created difficulties in linking the alterations (Alnoor et al., 2018). Additionally, responding to the short-term financial analysis has also been a difficult shift for big firms that have been preparing financial reports after the fiscal year. 
Financial reporting design is costly to develop. The current state of the firms that changed with new IFRS changes has faced high expenditure because of altering the guidelines. IFRS- 1 has developed the changes in the adoption of IFRS directives across the industries. In the same sense, the activities that involve the preparation of the final accounts have created a complex shift based on IFRS requirements (Alnoor et al., 2020). Therefore, the new implementation of IFRS guidelines has affected the adoption across the global financial reporting institutions and firms. The study evaluations show that the effectiveness of IFRS-1 in various corporate lack consistencies of the new alternative methods of financial reporting.

Consequently, the COVID-19 pandemic has influenced the effectiveness hence impacting the stability of financial reporting across different industries. Predominantly, standards of IFRS are unique depending on the report that firms are intending to prepare. Notably, a COVID-19 impact on IFRS has led to delayed preparation of statements, balance sheets, and profit and loss according to financial reports due to changes in the reporting period (Alnoor, 2020). The alteration from the long-term based reporting into the shortterm based reporting has been delaying the preparation of final financial accounts across global industries.

\subsection{Effects of COVID-19 on Shareholders Reporting}

Share income is prepared and presented in the company's income statements at the end of the twelve years. During the COVID-19 pandemic, IFRS requires implementing the reporting policy of share income in short-term reports of less than a year (Pandya, 2018). According to IFRS, the reporting system of the share income has been evaluated in the Trailing Twelve Months (TTM) model. However, the current IFRS reporting policy of share income is based on the Most Recent Quarter (MSQ) based on conditions of COVID-19 (Pandya, 2018). Financial analysis challenges presented during pandemic do not positively promise sound IFRS reporting systems across various industries.

Table 5: A sample of effects of COVID-19 of matching stock of top Companies in the U.S security market

\begin{tabular}{|l|l|c|c|c|c|c|c|}
\hline Name & $\begin{array}{c}\text { Price } \\
\text { (Intraday) }\end{array}$ & Change & $\%$ Change & Volume & $\begin{array}{c}\text { Avg Vol (3 } \\
\text { months) }\end{array}$ & $\begin{array}{c}\text { Market } \\
\text { Cap }\end{array}$ & $\begin{array}{c}\text { PE Ratio } \\
\text { (TTM) }\end{array}$ \\
\hline $\begin{array}{l}\text { HSBC Holdings plc } \\
\text { ADR A 1/40PF A }\end{array}$ & 25.8 & $-5.00 \%$ & 0 & 106,710 & 85,016 & $527.855 \mathrm{~B}$ & 54.66 \\
\hline BRK-A & $\begin{array}{l}\text { Berkshire } \\
\text { Hathaway Inc. }\end{array}$ & $314,333.88$ & $687888.00 \%$ & $2.24 \%$ & 444 & 1,114 & $509.12 \mathrm{~B}$ \\
\hline BRK-B & $\begin{array}{l}\text { Berkshire } \\
\text { Hathaway Inc. }\end{array}$ & 209.48 & $446.00 \%$ & $2.18 \%$ & $6.192 \mathrm{M}$ & $6.657 \mathrm{M}$ & $509.122 \mathrm{~B}$ \\
\hline V & Visa Inc. & 196.36 & $-241.00 \%$ & $-1.21 \%$ & $5.654 \mathrm{M}$ & $8.498 \mathrm{M}$ & $431.097 \mathrm{~B}$ \\
\hline BAC-PL & $\begin{array}{l}\text { Bank of } \\
\text { America } \\
\text { Corporation }\end{array}$ & $1,492.85$ & $-35.00 \%$ & 0 & 4,430 & 9,025 & $293.6 \mathrm{~B}$ \\
\hline JPM-PC & $\begin{array}{l}\text { JPMorgan } \\
\text { Chase \& Co. }\end{array}$ & 28.11 & $14.00 \%$ & 0 & 58,587 & 129,305 & $368.741 \mathrm{~B}$ \\
\hline SAN-PB & $\begin{array}{l}\text { Banco } \\
\text { Santander, } \\
\text { S.A. GTD } \\
\text { PFD SECS } 6\end{array}$ & 22.76 & $-11.00 \%$ & 0 & 14,497 & 12,988 & $350.06 \mathrm{~B}$ \\
\hline JPM-PD & $\begin{array}{l}\text { JPMorgan } \\
\text { Chase \& Co. }\end{array}$ & 27.5 & $1.00 \%$ & 0 & 83,864 & 141,161 & $365.354 \mathrm{~B}$ \\
\hline BAC-PK & $\begin{array}{l}\text { Bank of } \\
\text { America } \\
\text { Corporation }\end{array}$ & 27.17 & $-9.00 \%$ & 0 & 116,887 & 55,985 & $272.588 \mathrm{~B}$ \\
\hline JPM & $\begin{array}{l}\text { JPMorgan } \\
\text { Chase \& Co. }\end{array}$ & 99.38 & $214.00 \%$ & $2.20 \%$ & $14.744 \mathrm{M}$ & $22.585 \mathrm{M}$ & $302.87 \mathrm{~B}$ \\
\hline
\end{tabular}


Moreover, the companies are unable to meet the set longterm financial reports due to delayed reports of the venture of the new market niche. The tax structure applying to the shareholders and the financial reporting of companies have also changed due to adjustments to IFRS policies because of the COVID-19 pandemic effects (Aymen, 2018). Similarly, shareholders' reporting period under IFRS has been minimized to ensure continuous financial analysis due to the increased cost of financial accounts preparation (Benmelech \& Tzur-Ilan, 2020). Companies' shares undervalue, and buyback reports have changed their reporting timing via IFRS policies. IFRS guidelines reporting adjustment on shares have relatively changed to the possible inclusion of loss prediction on a short-term basis according to updates about the financial market.

\subsection{SWOT Analysis: Effects of COVID-19 to IFRS}

Table 6: IFRS SWOT Analysis

\begin{tabular}{|l|l|}
\hline $\begin{array}{l}\text { Strengths. } \\
\text { - Financial reporting }\end{array}$ & $\begin{array}{l}\text { Opportunities. } \\
\text { Technology }\end{array}$ \\
$\begin{array}{l}\text { - Human resource Involvement } \\
\text { - IFRS culture }\end{array}$ & $\begin{array}{l}\text { Innovation } \\
\text { Online report } \\
\text { Ilatforms }\end{array}$ \\
\hline $\begin{array}{l}\text { Weaknesses. } \\
\text { - Increase competition of } \\
\text { investment }\end{array}$ & $\begin{array}{l}\text { Threats. } \\
\text { - Numerous reporting levels } \\
\text { - High operation costs }\end{array}$ \\
& $\begin{array}{l}\text { Slowdown } \\
\text { Reporting } \\
\text { assumption }\end{array}$ \\
\hline
\end{tabular}

\subsection{IFRS-8 Departmental Operating Reports}

IFRS 8 requires a company to disclose information to evaluate the nature and financial effects of the different business activities in which it engages and the different economic environments in which it operates. The reporting of financial outcomes based on IFRS- 8 provides information according to the firm's financial position. Through the consolidation of accounting reports from different departments, the financial standard provides reports to the investors with a meaningful evaluation of the financial performance of the company's operations (Suryanto et al., 2016). Information is based on internal management reports, both in the identification of operating segments and measurement of disclosed segment information. The management oversees and provides the assumption through monitoring the performance of departmental operations. The framework of the financial reporting of the segments, according to IFRS-8, has been adjusted from the viewpoint of the management (Suryanto et al., 2016). COVID-19 has affected the adjustment of the departmental financial statements based on the development activities focusing on improving the financial reporting procedures (Suryanto et al., 2016). The segments provide reports from the manager's viewpoint, but due to the COVID-19, a system-based financial reporting that considers interim reporting rather than long-term based reporting concepts has been introduced.

\section{Methodology}

According to the research, qualitative analysis has been used because of the nature and the type of data required. Ethnographic searching was employed to acquire data from cybernetic systems because the source has enough information concerning stored data of IFRS. The research used cybernetic data to provide more exploration ways of adjusting financial reporting amidst COVID-19. Financial reporting, IFRS, and the impact of COVID-19 were the keywords used in search of data (Suryanto et al., 2016). The research investigated 55 files loaded with information relating to IFRS. 31 files had duplicated information and obsolete content.

The files selected also included the various countries that apply IFRS in their financial reporting systems. Additionally, some files exposed the countries that do not use IFRS in financial reporting. The study used 24 files from the selected data. Qualitative data obtained from the cybernetic system was assessed within the 24 files in the study. Repetitively, the study tested the data after filtering the duplicated files. The exclusion of unwanted data led to the final three sets of files used in the generation of the qualitative data, which was used in the research (Suryanto et al., 2016). Three files out of the five identified files assembled, provided data for the validity of the study. The design of the research helped the study to attain a significant part of the required outcomes.

Google Finance and Yahoo finance are two documentation processes in the qualitative assessment in the study. Additionally, the filtration of data provided the last data set that created the foundation for developing significant outcomes after sampling. The informationgathering was contained in the six datasets that helped the research to reach the results qualitatively. The study selected three files out of the gathered data and increased the validity by creating a random sampling procedure that facilitated the reduction of confounding during data sampling (Google Finance). According to the sampling method, the data was valid and had no errors that could affect the outcomes. 


\subsection{Random Sampling Method}

According to the research, the sampling method was fundamental because of the independent selection of sample files. Random sampling led to a generation of final files from the population of files extracted from online storage. The choice of the last three files used in the research was through random sampling (El-Helaly et al., 2020). The sampling procedure significantly increased the viability of the research and the realization of outcomes positive to the investigation. The selection of the samples was universal. According to Tahir et al. (2020), IFRS was the critical determinant of global financial reporting according to the files selected for evaluation.

26 files of the selected files were based on the effects of COVID-19 on financial reporting across the globe. 10 of the selected files showed adjusted IFRS having enabled financial reporting in line with the conditions presented by the pandemic (Fernandes, 2020). 24 files out of the extracted files contained information relating to the attempts of eliminating the challenges of financial reporting based on the epidemic and triggered IFRS changes. The research sampled ten files to show how IFRS created a conducive financial reporting environment. Of the 10 files sampled, IFRS policy-developers had information about the challenges the financial reporters faced based on the COVID-19 emergency (Frey et al., 2018). Consequently, data from random sampling was used to determine the adjustment of IFRS.

\subsection{Limitations of Random Sampling}

In the study, the probability of getting the wrong data through random sampling was possible because of the technique applied. This method encourages omission of terms in the search results in different data, thus distorting the final IFRS and COVID-19 data required. Also, all files containing IFRS and COVID-19 data where be included in the cybernetic search to ensure the exact data is accessed (Steccolini, 2019). Hence, the chances of accumulating wrong data in random sampling was high. The results from random sampling are a representation of a whole and large population and not guaranteed for application of the results worldwide. The reason as to why a challenge emerges in the application of the results globally indicates that the population may have diverse characteristics, for instance, impacts of COVID-19. Moreover, a small sample unit was used to represent the big population and might have fewer data compared to the whole population of files (Frey et al., 2018). Therefore, the results of random sampling do not guarantee universal application.

\subsection{Advantages of Random Sampling}

In the research, random sampling provides the simplest way of collecting data because only recording and observation skills are required. Compared to other processes of sampling, there is a low probability of classification errors as the data collected in the process is very accurate and trustworthy for implementation. In random sampling, every character has an equal chance of selection and, therefore, the elimination of bias. Repetitively, various types of randomness are used to eliminate bias in the research. Removal of bias resulted in reliable results of data in terms of fair characteristics and representation (Steccolini, 2019). As a result, random sampling is recommendable as it provides accurate and more reliable information for making decisions.

Additionally, carrying out random sampling requires less knowledge and not the specific details of IFRS and COVID-19 to select files that contained valid data. The selection involves simple acts that any person with or without the background knowledge of IFRS and COVID-19 can do it effortlessly (Frey et al., 2018). Hence, random sampling is very simple to carry out irrespective of the knowledge of the person involved. Out of the population files used in random sampling, the process of selecting the 55 sample units is easy as it is only a few groups that were selected from the whole population of files found in the cybernetic data system.

Due to the nature of the random sampling, the time consumed in retrieving data from cybernetic systems and in analyzing IFRS data concerning COVID-19 is quite low. In the research, only three groups are selected as sample units, as such the time taken in random sampling was less (Steccolini, 2019). Accordingly, the sample files selected have a high chance of representing the characteristics of IFRS and COVID-19 effects. Also, this study used fewer resources comprising the data that was required in determining the adjusted IFRS principles that align with COVID-19 conditions (Frey et al., 2018). Therefore, a considerable amount of money was spent on the random sampling process to get the final files that were used in the research.

\section{Data and Findings}

The collection of data was through an ethnographic method whereby the study obtained files from cloud storage. The files were searched using Google finance and Yahoo finance search engines via a data query method using keywords. IFRS, international, financial reporting, finance, profit, IFRS policies, and accounting were the words and phrases that were fundamental data values to call for the files (Steccolini, 2019). In addition to that, the data had files that were obtained with qualitative elements required sampling. 55 files were downloaded from the cloud storage from the government financial reporting websites that helped obtain real data. The selected files increased the validity of the outcome by adjusting IFRS file availability in the population of cloud storage (Steccolini, 2019). The gathering of the files included the name of the countries that apply IFRS in the local firms. Japan and the US were considered in the files as the variables that provided the actual information about the effects of the COVID-19 on IFRS. 
The data also included the variables IFRS guidelines from number 1-17 that provided the study data needs. Through descriptive design, the study selected the files through random sampling and increased the significance level of the research (Steccolini, 2019). The filtration of the data eliminated the duplicated files and reduced obsolete data if any. A random sampling of the files helped develop a suitable significant level and reduced the difference (Steccolini, 2019). Therefore, the data collection influenced the study's validity and the project's success in attaining the objectives.

\section{Discussion and Conclusion}

\subsection{Discussion}

According to the results of the study, the adjusted IFRS determines financial reporting with the effects of the COVID-19 pandemic. IFRS uses standardized procedures for setting the modified financial reporting system to cater to the challenges posed by COVID-19. IFRS has taken care of the uncertainties and judgment on entities by extending the time for financial reporting. Significantly, financial reporting has accepted the reporting of share-based payment to shareholders with short-term economic outcomes. Also, the study has developed fair value measurement (FVM) to cater to the new adjusted procedures of financial reporting of the forecasted price of the current market value of financial instruments (Steccolini, 2019). The adjusted IFRS comprises defaulters and loan payable breeches disclosure by providing financial reports of the ECL in short-term periods.

Consistently, the current discounts and reduced prices are included in short financial reporting. Reporting of liabilities has been justified on conditions an entity is operating with the current cash resource (El-Helaly et al., 2020). Therefore, adjusted financial reporting has considered the changed variables of market price values and provided a standardized way of financial reporting across the world.

The method of sampling used in the study to select files from the ethnographic search is random sampling. In the research, random sampling determines files used to generate data in determining the adjusted IFRS principles that align with COVID-19 conditions. A sample of 55 files is used as the total population sample of the study (Steccolini, 2019). Obsolete files are filtered through random sampling to select files with the most critical data. 31 files are excluded through filtration and resampling is done for the remaining 24 files to get the most relevant files with IFRS and COVID-19 as the keywords. The repetitive process of random sampling continues until three files with the necessary data are obtained. Random sampling has been very conversant with the study as the research has been characterized by main components which are IFRS and COVID-19 (Tahir et al., 2020). The data sampling outcomes have provided the final data used in determining the adjusted IFRS principles that align with COVID-19 conditions.

COVID-19 has created an ambiguous environment of financial reporting across the globe. The pandemic has triggered market price value fluctuation, making the initially set IFRS principles which were applied across the world unreliable. Consequently, IFRS policymakers are then forced to alter IFRS principles to ensure that financial reporting is well applicable in the current situation presented by the pandemic. The adjusted financial reports provide a good basis for financial reporting for firms facing the COVID-19 status quo. Hence, IFRS outlines new principles that cater to short-term reporting because of the changing market price values (Fernandes, 2020; Aymen et al., 2019). Hence, the adjusted IFRS are used worldwide to ensure standard financial reporting amidst COVID-19.

Also, the study presents countries using adjusted IFRS principles and how important they have been in financial reporting in the manifestation of the epidemic. Different countries consider using the adjusted IFRS based on the impact of COVID-19. The tremendous impact of adjusted IFRS has been felt while applying new set principles in countries with high effects of COVID-19, such as the US and Japan (Frey et al. 2018). Therefore, adjusted IFRS principles have enabled countries worst hit by the pandemic to provide financial reports without any difficulties.

\subsection{Managerial Implications}

This study has found that COVID-19 has undermined the consistency of IFRS application in various countries. The application of IFRS in the sampled countries shows the most affected financial reporting platform is the stock revenue and income outcomes of companies. The application of IFRS in the reporting system in the current financial market system allows the adjustments of accounting to prepare final reports on a short-term basis (Duong et al., 2020). Interim financial reporting is one of the emerging issues in the reporting systems due to the COVID-19 emergency. The evaluation results show that IFRS supports the adjustment of the existing policies to cope with the current pandemic situation (Dang et al., 2020). The reporting timing has been reduced, and the disclosure has been amended in IFRS-9 that guide the reporting of ECL. This aspect has been adjusted in the disclosure due to the assumption and quantification of the forecasted future cash flow.

On the other hand, the study showed that the use of IFRS in various financial reporting outcomes develops a guideline for coping with COVID-19. The US has been allowing local firms to use IFRS to advance the reporting system during pandemic emergencies (Steccolini, 2019; Abdulaali, 2018). IFRS helps the domestic firms to be prepared and report the financial outcomes under new disclosure of existing quantification assumptions of known values (Steccolini, 2019). The study found that the reporting timing has been 
adjusted into short-term and interim to the members and employees. In the same sense, the results show that Japan has been using IFRS since 2009 in domestic firms. In Japan, more than forty-six domestic firms apply IFRS in the reporting of financial outcomes. Japan has allowed the adjustment of IFRS policies that have changed the reporting timing and reduced the period of the final statements' preparation.

\subsection{Conclusion}

According to the findings, the study carried out provides evidence that COVID-19 affects financial reporting in firms across the world. The firms have a hard time presenting the reports on the finances based on the challenging environment presented by the pandemic. Consequently, COVID-19 has led to adjusting IFRS to ensure that financial reporting is consistent as per the state of the condition created. Moreover, the study presents an agreement of the use of changed IFRS in financial reporting because of COVID-19. Also, the adjusted financial reporting period provides uniform reporting procedures of the financial transactions across the globe despite the pandemic. Therefore, IFRS has been used to curb the challenges faced in financial reporting by observing social distancing duration during reporting matters to eradicate firm uncertainty and judgment.

Besides, the adjusted IFRS's fair value measurement (FVM) considers the prices which have been forecasted as per the present market values. Also, IFRS caters to the share-based payment reporting to ensure that the short-term outcomes of the economy to shareholders are well captured. In financial reporting, the defaulted and breached loans that COVID-19 has forced are indicated and the expected credit loss (ECL) assessment reports are provided. Profoundly, IFRS provides a way of reporting financial outcomes in a short time. The short-term reporting takes care of the currently issued discounts and the reduced prices consistently. The ambiguous situation has been combated by the adjusted IFRS and made the financial reporting align with the current COVID-19 situations. Despite the COVID-19 adverse challenges, financial reporters now have a relevant way of providing the reports. The policymakers indicate an improvement of financial reporting with the use of adjusted IFRS to meet the optimal goal of financial reporting. Consequently, the firms involved in financial reporting converge with changed IFRS to adopt a focused and effective financial reporting amidst challenges by COVID-19.

\section{References}

Abdulaali, A. R. (2018). the impact of intellectual capital on business organizations. Academy of Accounting and Financial Studies Journal, 22(6), 1-16. https://doi.org/ 1528-2635-226-303
Al-Abrrow, H., Ali, J., \& Alnoor, A. (2019). Multilevel influence of routine redesigning, legitimacy, and functional affordance on sustainability accounting: Mediating role of organizational sense-making. Global Business Review. November 15, 1-26 https://doi.org/10.1177/0972150919869726.

Al-Abrrow, H., Alnoor, A., \& Abbas, S. (2019). The effect of organizational resilience and CEO's narcissism on project success: Organizational risk as a mediating variable. Organization Management Journal, 16(1), 1-13. https://doi.org /10.1080/15416518.2018.1549468.

Alhamdi, M., Noor, R. M. A. S., Abdulla, M., Alnoor, A., \& Eneizan, B. (2019). How does financial analysis influence the firm's failure in the Iraqi private sector? The Journal of Social Sciences Research, 5(9), 1321-1328. https://doi.org/10.32861/ jssr.59.1321.1328.

Alnoor, A. (2020). Human capital dimensions and firm performance, the mediating role of knowledge management. International Journal of Business Excellence, 20(2), 149-168. https://doi. org/10.1504/IJBEX.2020.105357.

Alnoor, A. M., Al-Abrrow, H., Abdullah, H., \& Abbas, S. (2020). The impact of self-efficacy on employees' ability to accept new technology in an Iraqi university. Global Business and Organizational Excellence, 39(2), 41-50. https://doi. org/10.1002/joe.21984.

Alnoor, A., Eneizan, B., Makhamreh, H. Z., \& Rahoma, I. A. (2018). The effect of reverse logistics on sustainable manufacturing. International Journal of Academic Research in Accounting, Finance and Management Sciences, 9(1), 71-79. http://dx.doi. org/10.6007/IJARAFMS/v9-i1/5768.

Asumadu, E., \& Das, S. (2018). Corporate financial reporting: A study on the IFRS regime in Ghana and around the world. International Journal of Management Reviews, 4(3), 1-11. https://doi.org/ 10.18843/ijms/v5i4(3)/01.

Aymen, R. A., Alhamzah, A., \& Bilal, E., 2019. A multi-level study of influence financial knowledge management small and medium enterprises. Polish Journal of Management Studies, 19(1), 21-31. https://doi.org/ 10.18843/ijms/v5i4(3)/01.

Benmelech, E., \& Tzur-Ilan, N. (2020). The determinants of fiscal and monetary policies during the COVID-19 crisis (No. w27461). National Bureau of Economic Research, 1(3), 1-42. https://doi.org/ 10.3386/w27461.

Bharti, B., \& Kumar, A. (2020). Herding in the fast-moving consumer group sector: Equity market asymmetry and crisis. Journal of Asian Finance, Economics, and Business, 7(9), 39-49. https://doi.org/10.13106/jafeb.2020.vol7.no9.039

Burton, G. F., \& Jermakowicz, E. K. (2015). International financial reporting standards: a framework-based perspective. London, UK: Routledge.

Dang, H. T., Phan, D. T., Nguyen, H. T., \& Hoang, L. H. T. (2020). Factors affecting financial risk: evidence from listed enterprises in Vietnam. Journal of Asian Finance, Economics, and Business, 7(9), 11-18. https://doi.org/10.13106/jafeb.2020. vol7.no9.011 
Duong, T. T. N., Phan, H. T., Hoang, T. N., \& Vo, T. T. T. (2020). The effect of financial restructuring on the overall financial performance of the commercial banks in Vietnam. Journal of Asian Finance, Economics, and Business, 7(9), 75-84. https:// doi.org/10.13106/jafeb.2020.vol7.no9.075.

El-Helaly, M., Ntim, C., \& Al-Gazzar, M. (2020) Diffusion theory, national corruption, and IFRS adoption around the world. Journal of International Accounting, Auditing, and Taxation, 38(1), 1-22. https://doi.org/10.1016/j. intaccaudtax.2020.100305.

Eneizan, B., Mohammed, A. G., Alnoor, A., Alabboodi, A. S., \& Enaizan, O. (2019). Customer acceptance of mobile marketing in Jordan: An extended UTAUT2 model with trust and risk factors. International Journal of Engineering Business Management, 11(11), 1-10. https://doi. org/10.1177/1847979019889484.

Fernandes, N. (2020). Economic effects of coronavirus outbreak (COVID-19) on the world economy. Available at SSRN: https:// ssrn.com/abstract=3557504 or http://dx.doi.org/10.2139/ ssrn.3557504.

Frey, G. E., Cubbage, F. W., Ha, T. T. T., Davis, R. R., Carle, J. B., Thon, V. X., \& Dzung, N. V. (2018). Financial analysis and comparison of smallholder forest and state forest enterprise plantations in Central Vietnam. International Forestry Review, 20(2), 181-198. https://doi.org/10.1505/146554818823767582.

Hadi, A. A., Alnoor, A., \& Abdullah, H. O. (2018). Socio-technical approach, decision-making environment, and sustainable performance: Role of ERP systems. Interdisciplinary Journal of Information, Knowledge, and Management, 13(2), 397-415. https://doi.org/10.28945/4149.

Oztürk, H., \& Karabulut, T. A. (2018). The relationship between earnings-to-price, current ratio, profit margin, and return is an empirical analysis of the Istanbul stock exchange. Accounting and Finance Research, 7(1), 109-115. https://doi.org/10.5430/ afr.v7n1p109.

Pandya, V. U. (2018). Mergers and acquisitions trend: The Indian experience. International Journal of Business Administration, 9(1), 44-54. https://doi.org/10.5430/ijba.v9n1p44.

Steccolini, I. (2018), Accounting and the post-new public management: Re-considering publicness in accounting research, Accounting, Auditing \& Accountability Journal, 32(1), 255-279. https://doi.org/10.1108/AAAJ-03-2018-3423.

Sumani, S., \& Roziq, A. (2020). Reciprocal capital structure and liquidity policy: Implementation of corporate governance toward corporate performance. Journal of Asian Finance, Economics, and Business, 7(9), 85-93. https://doi.org/10.13106/ jafeb.2020.vol7.no9.085

Suryanto, T., \& Ridwansyah, R. (2016). The Shariah financial accounting standards: How they prevent fraud in Islamic Banking. European Research Studies, XIX(4), 140-157. https:// doi.org/2016i4p140-157.

Tahir, S. H., Tahir, F., Syed, N., Ahmad, G., \& Ullah, M. R. (2020). Stock market response to terrorist attacks: An event study approach. Journal of Asian Finance, Economics, And Business, 7(9), 31-37. https://doi.org/10.13106/jafeb.2020.vol7.no9.031 